\title{
Co-Existence of Polyneuropathy, Osteoporosis and Limb Girdle Muscular Dystrophy in a Patient with Ankylosing Spondylitis
}

\section{${ }^{1}$ Hasan ArmaganUysal, ${ }^{2}$ Filiz Meryem Sertpoyraz, ${ }^{3}$ Bedile İrem Tiftikcioglu}

${ }^{1}$ University of Economy, Medical Park İzmir Hospital, Department of Neurology, Izmir, Turkey

\section{${ }^{2}$ University of HealthSciences,}

Tepecik EducationandResearchHospital, Department of PhysicalTherapyand Rehabilitation, Istanbul, Turkey

${ }^{3}$ University of Bakırçay, Cigli EducationandResearchHospital, Department of Neurology,Izmir, Turkey

\section{Correspondence:}

Hasan Armağan UYSAL

University of Economy, Medical

Park İzmir Hospital, Department of

Neurology, Izmir, Turkey

e-mail: druysalarmagan@yahoo.com

\section{Abstract}

In this paper, we aimed to report a case of limb-girdle muscular dystrophy with diabetes mellitus who admitted to our outpatien clinic with paresthesia in all four limbs and swelling and pain in both ankles and waist. Nerve conduction study affirmed peripheral sensory polyneuropathy and osteoporosis was detected by bone mineral density analysis. A detailed evaluation revealed bilateral sacroiliitis, HLA-B 27 positivity, and elevation of erythrocyte sedimentation rate and serum C-reactive protein levels. Thus, the diagnose of ankylosing spondylitis was confirmed. It is worth presenting because the diagnoses of limb-girdle muscular dystrophy, diabetic polyneuropathy, osteoporosis, and ankylosing spondylitis were observed together in the same patient.

Keywords: Limb-girdle muscular dystrophy, Ankylosing spondylitis, Osteoporosis, Polyneuropathy

\section{Özet}

Bu yazıda, önceden Limb-girdle muskuler distrofi tanısı olan, polikliniğimize dört ekstremitede parestezi ve şişlik, hem bel hemde ayak bileğinde ağrı olması nedeniyle başvuran diyabetik bir hastayı sunmayı amaçladık. Sinir iletim çalıșmasında periferik duysal nöpolinöropati olduğu doğrulandı ve kemik mineral yoğunluk analizi ile osteoporoz saptandı. Yapılan ayrıntılı değerlendirme ile bilateral sakroileit, HLA B27 pozitifliği, eritrosit sedimentasyon hızı ve serum C-reaktif protein yüksekliği ortaya koyuldu. Böylece, ankilozan spondilit tanısı kesinleștirildi. Hastada, Limb girdle muskuler distrofi, diabetik polinöropati, osteoporoz ve ankilozan spondilit tanılarının birarada gözlenmiş olması nedeniyle sunulma değer bulunmuşur.

Anahtar Kelimeler: Limb-girdle muskulerdistrofi, Ankilozanspondilit, Osteoporoz, Polinöropati 


\section{Introduction}

Limb-girdle muscular dystrophies (LGMD) are a heterogeneous group of autosomal recessive and dominant disorders characterized by progressive weakness of the shoulder and pelvic-girdle muscles.

Ankylosing spondylitis (AS) is a chronic, systemic, autoimmune, and inflammatory rheumatic disease, which primarily affects the vertebral and sacroiliac joints of the body.

Peripheral neuropathy is one of the most common complications of diabetes mellitus that micro inflammatory changes have also been proposed in the highly complex disease pathogenesis. Painful paresthesia in distal limbs and symptoms due to the involvement of the autonomic nervous system is frequently seen in those patients.

Osteoporosis is a skeletal disorder characterized with decreased bone mineral density and disruption in the structural integrity of bones that increases the risk of fractures, significantly. Ageing has been defined as an important risk factor for osteoporosis; however, immobilization, inflammatory rheumatic disorders, and various endocrine diseases might also precipitate osteoporosis by decreasing the load on the bones.

We described a patient diagnosed with limbgirdle muscular dystrophy and multiple autoimmune diseases (namely, AS and DM) and discuss the possible pathogenesis in line with the literature.

\section{Case Report}

A 46-year-old man was admitted with the complaint of painful and swollen ankles, stiffness in neck and limb joints, and paresthesia in distal limbs. He was diagnosed with limb-girdle muscular dystrophy 20 years ago, with the symptoms of slowly progressive weakness in proximal limb muscles, which started during his early twenties, increased levels of serum creatinine kinase (CK), myopathic changes in electromyography, and dystrophic changes in muscle biopsy. LGMDdystroglycanopathy was diagnosed and in sequence analysis of the genes homozygote fukutin-related protein gene mutation was detected. He was diagnosed with Type-2 Diabetes Mellitus (T2DM) 10 years ago. His daughter was diagnosed with ankylosing spondylitis and was using non-steroid antiinflammatory medications, besides regular physiotherapy. Ten years ago, he was operated due to right femur fracture after a fall and was unable to walk after a one-year period of postoperative immobilization.

He was using a wheelchair and his modified Rankin score was 4. Examination revealed severe atrophy in the shoulder and pelvicgirdle muscles. Cervical mobility was painful and restricted in all directions. Dorsal kyphosis was increased. There were flexion contractures in both hip joints and right knee. Bilateral sacroiliac joints were painful with palpation. Lumbar motility could not be evaluated. Right ankle was swollen and warm with arthralgia. Muscle strength was $2 / 5$ in proximal and $3 / 5$ in distal muscles in upper limbs, and 2/5 in both the lower limbs. He had distal symmetric hypoesthesia in stocking and glove distribution. He was severely dependent with Barthel index score as 25.

Serum and urine biochemical tests were within normal limits except erythrocyte sedimentation rate $(53 \mathrm{~mm} / \mathrm{h})$, serum Creactive protein $(1.97 \mathrm{U} / \mathrm{dL})$, creatinine kinase (459 U/dL), and lactic dehydrogenase (601 U/dL). HLA-B 27 was positive. Sacroiliac joint magnetic resonance imaging (MRI) revealed bilateral ankylosis. There was edema in the right ankle and epin formation in right calcaneus and syndesmosis in C3-4-5-6 cervical vertebral corpuses in direct X-ray graphy. Total Z-score in hip was -2.6 in bone mineral density. Distal symmetrical sensory polyneuropathy was detected in electrodiagnostic studies.

He was treated with indomethacine $75 \mathrm{mg} / \mathrm{d}$, salazopyrin $2000 \mathrm{mg} / \mathrm{d}$, pregabaline $150 \mathrm{mg} / \mathrm{d}$ and dalendronate $70 \mathrm{mg} / \mathrm{w}$ with cholecalciferol $2800 \mathrm{IU} / \mathrm{w}$. He was enrolled in a personalized physiotherapy program. CRP level and sedimentation rate were decreased 3 months later. Total Z-score in hips was increased to 1.6 one year later. 


\section{Discussion}

We present a patient with limb-girdle muscular dystrophy accompanied by ankylosing spondylitis, and diabetes mellitus. LGMD is a heterogeneous group of disorders characterized by progressive weakness and atrophy in shoulder and pelvic girdle muscles with autosomal recessive or autosomal dominant traits. Clinical and pathological symptoms might involve the nervous and gastrointestinal systems as well as the musculo-skeletal, respiratory and cardiovascular systems (1). LGMDdystroglycanopathies are a group of rare, progressive genetic disorders which is associated with FKRP gene mutations. A wide spectrum of clinical severity based on the age of onset, the degree of myogenic atrophy are reported (2-Kanagawa M). Homozigote gene mutation in FKRP has been detected in our patient. He was diagnosed in his 20 s'.

Ankylosing spondylitis (AS) is a chronic, inflammatory rheumatic disorder with autoimmune nature, which mainly affects vertebral and sacroiliac joints. Although inflammatory low back pain is a characteristic feature, peripheral articular or non-articular involvement could also be seen. Axial skeletal involvement leads to progressive deformation of vertebral colon due to spondylitis, enthesitis, syndesmophyte, and sacroiliitis (3). HLA-B27 allele is common in spondyloarthropathies, particularly in AS (4). Diagnosis of AS is mainly based on New York criteria (5). Our patient was diagnosed with AS due to inflammatory low back pain, bilateral grade 4 sacroiliitis, HLA-B27 (+), and family history.

The co-existence of AS with various neurological symptoms and disorders such as arachnoiditis, cauda equina syndrome, multiple sclerosis, and complications due to spinal stenosis and vertebral fractures has been reported. Neurological complications such as cervical myelopathy, radiculopathy, myopathic features in supraspinatus and trapezius muscles have been reported in a study of 24 patients with AS (6). Ozturk et al reported that patients with AS have more fatty degeneration and denervation in paraspinal muscles in sonographic, electrophysiological and magnetic resonance imaging (7). Type 1 and 2 fiber atrophy was detected besides small, dispersed, sharp angular fiber changes. It is concluded that AS patients with dorsal kyphosis might present with myopathy. In another study carried out on 30 AS patients, although, $46.4 \%$ of patients with higher levels of $\mathrm{CK}$ had myopathic features in electrodiagnostic studies, these findings were not in association with clinical symptoms in $66 \%$ of them. Authors have suggested that muscular symptoms were a consequence of inflammatory status (8). Recently, two mechanisms have been proposed in the muscular atrophy and function loss in patients with AS; (a) radiculitis with paravertebral muscle involvement or (b) non-specific, diffuse muscular involvement. Myopathic changes in electromyography, and dystrophic muscle fibre changes in muscle biopsy is shown in our patient.

Akgul et al have argued that lipodegeneration in lumbar paravertebral muscles (i.e. $\mathrm{m}$. erector spina, m. multiphidius and m. psoas) was secondary to the chronicity and loss of function in those muscles (9). In a case report of a patient with fascioscapulohumeral muscular dystrophy (FSHMD) and AS, authors reported that FSHMD could be secondary to immune inflammation in which the same mechanisms were accused in etiopathogenesis of AS (10).

Diabetic peripheral neuropathy, particularly associated with extended hyperglycemia, usually presents with paresthesia, hyperalgesia, and autonomic dysfunction. Our patient was diagnosed with diabetic peripheral neuropathy with similar symptoms, confirmed with electrodiagnostic studies. T2DM was the second most frequent co-morbid disease after thyroid diseases in Turkish patients with AS, in accordance with a cohort study, which reported that prevalence of T2DM and its related complications were highly frequent among Asian AS patients (11-14). Routine screening for the presence of DM should be a part of evaluation of these patients during the follow up period for early detection of this comorbidity (12). In addition, several other reports emphasize the co-incidence of various 
muscular diseases with polyneuropathies. It has been reported that mild peripheral neuropathy could be seen in patients with muscular or myotonic dystrophy due to the genetic defect in peripheral myelin protein $(14,15)$. Chan et al have reported axonal sensorimotor polyneuropathy in a 10 -year-old girl with LGMD, who had elevated CK and laminin-2 deficiency with dystrophic changes in muscle biopsy (15).

Osteoporosis, characterized with decreased bone mineral density and destruction of microarchitecture of bone structure, is usually related with advanced age; however, immobilization, a decrease of load on bones due to muscle weakness, and other secondary etiologies could amend osteoporosis to earlier ages. Steroids used for muscular dystrophies significantly increase the risk together with

\section{REFERENCES}

1. Angelini C. LGMD. Identification, description and classification. Acta Myol. 2020;39:207-17

2. Kanagawa $M$, Kobayashi $K$, Tajiri $M$, et al.Identification of a Post-translational Modification with Ribitol-Phosphate and Its Defect in Muscular Dystrophy. Cell Reports 2016; 14:2209-23

3. Taurog JD, Chhabra A, Colbert RA. Ankylosing Spondylitis and Axial Spondyloarthritis. N Engl $J$ Med. 2016;374:2563-74.

4. Parameswaran P, Lucke M. HLA B27 Syndromes. 2021 Jul 10. In: StatPearls [Internet]. Treasure Island (FL): StatPearls Publishing; 2021. PMID: 31855367.

5. Braun J, Baraliakos X, Buehring B, et al. Imaging of axial spondyloarthritis. New aspects and differential diagnoses. Clin Exp Rheumatol. 2018;114:35-42.

6. Khedr EM, Rashad SM, Hamed SA, et al. Neurological complications of ankylosing spondylitis: neurophysiological assessment. Rheumatolint. 2009;29:1031-40.

7. Ozturk EC, Yagci I. The structural, functional and electrophysiological assessment of paraspinal musculature of patients with ankylosing spondylitis and non-radiographic axial spondyloarthropathy. Rheumatol Int. 2021 Mar;41:595-603

8. Faus-Riera S, Martínez-Pardo S. Muscle pathology in ankylosing spondylitis: clinical, enzymatic, electromyographic and histologic correlation. J Rheumatol. 1991;18:1368-71.

9. Akgul O, Gulkesen A. MR-defined fat infiltration of the lumbarparavertebral muscles differs between non-radiographic axia spondyloarthritis immobilization (16). Our patient had almost all of these risk factors (muscle weakness, immobilization, low levels of vitamin $\mathrm{D}$ due to decreased contact with sun, inflammatory mediators of AS, and endocrinopathy (i.e. T2DM)), which have accelerated the development of osteoporosis. Unfortunately, our patient had had an operation due to pathological femur fracture secondary to osteoporosis. Early interventions immediately after the diagnosis have been proposed to prevent fractures.

\section{Conclusion}

There is need for comprehensive studies in regard with muscular involvement in patients with AS. Moreover, it should be kept in mind that various co-morbidities such as polyneuropathy could occur in patients with muscular dystrophy.

and established ankylosing spondylitis. Mod Rheumatol. 2013;23:811-6.

10. Alagoz AN, Öztürk Ş. Fasioskapulohumeral Musküler Distrofi ve Ankilozan Spondilit Birlikteliği. F.Ü.Săg.Bil.TıpDerg.2010:24:51-4

11. Chen HH, Yeh SY, Chen HY, Lin CL, Sung $\mathrm{FC}$, Kao $\mathrm{CH}$. Ankylosing spondylitis and other inflammatory spondyloarthritis increase the risk of developing type 2 diabetes in an Asian population. Rheumatol Int. 2014;34:265-70.

12. Hasan ATMT, AbdulAlim M. Prediabetes \& Diabetes Among Patients with Axial Spondyloarthritis, European Journal of Clinical and Biomedical Sciences 2020; 6:116-19

13. Serda Em, Mehtap Bozkur. Ankilozan spondilitli hastalarda komorbit hastalıkların değerlendirmesi, Dicle tıp dergisi 2014;41:662-6

14. Madej-Pilarczyk A, KotruchowK. EmeryDreifuss muscular dystrophy type 2 associated with mild peripheral polyneuropathy. Folia Neuropathol. 2015;53:270-4.

15. Chan SH, Foley AR, Phadke R, et al. Limb girdle muscular dystrophy dueto LAMA2 mutations: diagnostic difficulties due to associated peripheral neuropathy. Neuromuscul Disord. 2014;24:677-83

16. Bell JM, Shields MD, Watters J. et al Interventions to prevent and treat corticosteroidinduced osteoporosis and prevent osteoporotic fractures in Duchenne muscular dystrophy. Cochrane Database SystRev 2017, 24:1:CD010899. 